\title{
Krimuning's Laku Action in Novel KrimuningDewiOntang-Anting :Javanese Religious Studies
}

\author{
Rizky Nuraini ${ }^{1}$ and Turita Indah Setyani ${ }^{2}$ \\ \{Rizkynuraini13@gmail.com ${ }^{1}$,turita.indah@ui.ac.id²\} \\ ${ }^{1,2}$ Javanese Study Program, Faculty of Humanities, Universitas Indonesia, Indonesia
}

\begin{abstract}
The novel KrimuningDewiOntang-Anting (KDOA), published in Semarang in 2017, contains the religious aspects of KarimunJawa society. This study aims to examine the religious aspects of Javanese life in the 21 st century as illustrated in the novel KDOA. In particular, to understand the laku done by the character Krimuning in the novel. This study uses the theory of laku in the perspective of Javanese religion with an objective approach. The benefit of this research is to give an idea of laku of the KarimunJawa society represented by Krimuning in the novel KDOA. The result of the analysis reveals that Krimuning represents the laku of KarimunJawa society in terms of their anxiety in facing life. The conclusion of the research is that in the modern era, laku still have a very important role in KarimunJawa societyas described in the novel KDOA.
\end{abstract}

Keywords: laku, Krimuning, DewiOntang-Anting, KarimunJawa society

\section{INTRODUCTION}

In the context of Javanese culture, there are many ceremonies and activities performed, such as the sedekahbumi, tolakbala, bersihdesa, as well as selamatan which correlated with life cycle, from gestation, birth, to death. However, nowadays, it seems that these rituals are only limited to physical worships which gradually become increasingly eroded in terms of their meanings. Therefore, some groups of Javanese society try to keep the depth of meanings of the traditional ceremonies by seeking appreciation to the core of worldly life and spiritual life. Javanese perform this appreciation by doing olah rasa. This activity is generally studied in communities and/or mysticism belief.

The community and/or mysticism belief that developed in Javanese society is known as kejawen 'kejawaan' or 'Jawanisme'[1]. The adherents of kejawen do not regard their teachings as monotheistic religions or as the major religions that exist in Indonesia, but their existence is acknowledged by the wider Javanese community.

The community and/or adherents of kejawenis one of the cultures for the Javanese. In the culture, there are activities that become the characteristics of each of them, such as how to become a member, how to worship, religious activities performed, and the religious orientation. It is the religious activity that in Javanese society is categorized as action laku. 
In the treasury of Javanese literature, the laku-laku are scattered as a part of various literary works. One of them is in the novel Krimuning Dewi Ontang-Anting (hereinafter written KDOA). KDOA, written by Widyo Babahe Leksonoin Javanese, has the background of the village life in Karimun Island Java and was published in 2017 by Cipta Prima Nusantara, Semarang. The novel consists of 75 chapters and 229 pages[2]. Referring to the background, the content of the story, and the year of the publication, it can be said that the novel has its own distinctiveness in presenting the practice of laku in modern times.

Broadly speaking, the novel reflects the laku of the main character, Krimuning in getting around her personal life related to wayah candhikala feared by the villagers coincides with the time when her father died and the time of her birth. To know about the wayah candhikala, Krimuning performs laku. He learns a lot and asks guidance to a respected figure who is considered to have knowledge in her village. Scrutinizing the contents of KDOA published today but narrating the course of laku carried out by the main character, it can be interpreted that lakuis still relevant today. Therefore, the KDOA novel needs to be studied more deeply to find out the lakuin it, and how the community in Karimun Jawa responds to the laku. The purpose of this study is to examine the laku conducted by Krimuning in KDOA in the context of Javanese religion on the life of society in the 21 st century.

Therefore, to describe the laku in the novel KDOA, it requires religious knowledge as the background of the story. In addition, to support the data analysis, this research utilizes two articles that are considered relevant as well as a book that discusses the concept of laku in the Java culture.

First, the article from Afnan that discusses the ritual performed by the members of the "True Science" group as a daily practice of Sufism. The practice consists of four actions, compulsory prayer and Sunna (evening prayer), munajat, tirakat, and khalwat [3]. The laku of Sufism can provide knowledge to deliver this study, which is more or less the same as the laku carried out by Krimuning, such as prayers, fasting, ruwatan, and semedi. Although the perspectives used in the article is from the Islamic point of view, while this study is in the Javanese religious perspective, but the laku that is carried out has the same goals and achievements.

Second, an article by Ikhsan that illustrate the local values of the Cetho village settlement structure on the slopes of Mount LawuKaranganyar, Central Java with a Hindu-Javanese cultural background. The result of the research reveals that local values in Cetho Village are based on the philosophy of Memayu Hayuning Bawana. This concept of philosophy is abstracted into various aspects of settlements in Cetho Village, such as the existence of two ritual activities that are assembled with Ruwatan events, named Mondosiyo and Dawuhan. Through this ritual, the villagers recover water sources that exist to always meet the needs of water enough for all citizens. In addition, for them, the water source is a sacred place because water is used for all the necessities of life and serves as a complementary ritual of worship [4]. Both rituals may be referred to Ruwatan done by Krimuning in KDOA.

Third, the book entitled " Guru Sejati: Jalan untuk Menemukan Kemurnian Abadi di Antara Kekotoran Duniawi." The book explains that humans can discover identity through the whisperings of a true teacher. In Javanese religion, a true teacher is a mysterious figure, a magical figure that will show human life on a straight path. True teachers are in charge of guiding people to always be in stable awareness. For humans who have a close relationship with a true teacher, they have a strong faith and are hard to be shaken [5]. The person who is able to find a true teacher is very fortunate, as it is an extraordinary inner experience. One of the signs of the achievements is that one is allowed by God to know what will happen in the future through vision, dream, and the vibration of conscience. Such inner experience and 
accomplishments can be gained by performing laku. In the teachings of kejawen done in various ways, such as with the laku prihatin through the four stages that must done completely. The four stages are figured into the tone of the Javanese Gamelan instrument called Kempul or Kenong and Bonang which sound; neng (jumeneng: standing, conscious, tirakat, semedi), ning (wening: silence, solemnity, creativity), nung (victory: elected, great grace from God), and nang (win: victory, grace, pleasure, provide benefits) [5]. The description of the inner experience from the book will be referred to describe laku carried out by Krimuning in the KDOA novel.

\section{METHOD}

On the whole, to reveal the study of lakuin the novel KDOA is by using the theory of laku in the perspective of Javanese religion with an objective approach. The objective approach is used to place the KDOA novel as an autonomous literary work in revealing the importance of lakuas reflected in it. The Javanese religious perspective is useful to understand the text. Understanding of the text is more focused on the laku in the KDOA novel. Understanding departs from the theory of laku based on the Javanese religious perspective which is giving the impression, opinion and / or views on something related to the interpretation of the laku. The interpretation itself is an attempt to uncover the laku in accordance with the first or original intention based on what is written in the KDOA novel.

\section{RESULT AND DISCUSSION}

KDOA novel has a background of Alang-alang village life in Karimun Island Java. Life in the village can be categorized as modern enough. This is reflected in the mobile communication tool used by the characters and the internet world that has been exploited by its citizens. However, the residents still maintain the culture that exist in their village, one of which is to support the laku done by Krimuning to overcome life.

Javanese always practice laku with olah rasa to improve the level of perfection, so that they are always in a state of harmony and blend with the purpose of the cosmos. However, religious laku has an influence on the human consciousness system, so that humans can cultivate feelings to lead to the completeness of life [5].

In the KDOA novel, laku is represented by a girl named Krimuning for her anxiety to find the real answer of what and who the candhikala is, why the villagers of Alang-alang on Karimun Island where she lives talk about it, even afraid of wayahcandhikala - 'time before sunset'.

There are various opinions about the candhikala, such as related to the types of wanci,wayah - 'time', and buta - 'the giant'. In the meantime, Krimuning is thinking of some place. In addition, her anxiety was caused by a sense of curiosity towards the villagers' talks about her father's death when he went to sea at sunset (wayahcandhikala), so it is considered preyed by Candida Candhikala - 'GiantCandhikala'. After her father's mitungdina - '7 days of death', Krimuning starts looking for sisikmelik - 'bright spot' of the incident. From that moment, every time before the evening, Krimuning went out to look for answers by sitting on a rock, called a 'masked stone' by the local village community. After the sun sets, though not yet found the answer, she returns home [2]. Thus, the objective of laku carried out by Krimuning in the KDOA novel is to find answers to her anxiety about wayahcandhikala and / or the ButaCandhikala.

In the conduct of laku, Krimuning asks MbahJito, a village elder who is considered to have the capability of mysticism in Javanese culture. MbahJito often helps the villagers, including 
to cure the illness suffered by them. After obtaining a clue from MbahJito, Krimuning carries out four actions that are summarized in the KDOA novel, such as prayer, Monday-Thursday fasting, ruwatan, and semadi (tapa). Such laku may be described as follows.

\subsection{Prayer}

Krimuning has always performed the daily prayers, as evidenced by the words of her mother who asked to perform the Maghrib prayer and Tahajud prayer [2]. It shows that she is a Muslim and obedient to do the Islamic Shari 'a, even the Sunna. In Javanese culture, lakusalat is included in the category of worship at the four levels of worship (body, creations, souls, feelings) contained in the SeratWedhatama, that is as a physical act moves to obey God's commands. The action is also called the lakusarengat which is aligned as Shari ' $a$ in Islam [6]. Islam, referring to the views of Dikhorir (2017), the obligatory prayers and the Sunna of night prayers are the laku of Sufism.

In the Qur'an, it is explained that Allah SWT guarantees the feelings of calm and peace for people who offer prayers sincerely. Even Allah says that the solemn servants meet God in their prayers. Therefore, according to the literal meaning, prayer is to meet God (liqa'ullah) $[3]$.

The prayer done by Krimuning, can be said as the laku of Sufism, trying to get closer and meet God to obtain calmness over her anxiety against her mind about candhikala. Although she has obtained calm, the problem of wayahcandhikala and the cause of his father's death in her mind has not been answered, so Krimuning continue to look for the sisikmelik to know what and who candhikala is.

\subsection{Fasting}

MbahJito has explained repeatedly about wayahcandhikala, but Krimuning remains dissatisfied with the answer. For that, MbahJito advises Krimuning to do laku, which is called ilmutuwa - 'old science,' like the following quote:

"Iki ilmu tuwa ya, Ndhuk! Gak enthuk sembrana. Nek dibabar marang sing durung umur, isa-isa dadi kojur"'[2].

"This is old science, son! You should not be careless. If delivered to the underaged, it can lead to misery."

However, prior to the conduct of such laku, Krimuning is requested to perform the fast on Monday and Thursday first in the period determined by MbahJito. In Javanese religion, fasting is one of the actions that is executed as a tiraqat for a person who is forging oneself, in cultivating feelings, in order to always be aware of his desires. Tirakat in Islam according to Dikhorir (2017) is one of the lakutasawuf.

In the spiritual deepening tradition of kejawen, it is performed to increase the power and spiritual ability of metaphysics. The tradition of fasting is a method to awaken the spirit of self, in order to become a human with a strong soul and a broad mind, so as being able to achieve spiritual elevation [5].

Thus, Monday-Thursday fasting by Krimuning, which is to control and realize the worldly desires from thoughts that affect her, to be broad-minded, have strong soul, can build a spirit of self to improve her spirituality, so as to receive any clues that will be obtained at the next laku. Therefore, MbahJito also ordered Krimuning to no longer thinking about wayah and / or butacandhikala. 


\subsection{Ruwatan}

In Javanese culture, ruwatan ceremony is basically intended for children to be free from all distress, distractions, accidents, and others [7]. The KarimunJawa community in the KDOA novel also still believes and performs the ruwatan tradition. They know the ruwatan ceremony, as described by MbahJito, is a Javanese custom or culture to eliminate the sukerta - 'disturbance' or clean up the rereget - 'filth'. The examples of children which are included as sukerta is also described, such as anting-anting - 'single child', both male and female; uger-ugerlawang -'two sons;' kembangsepasang -'two daughters'; kedhanakedhini-'two children' (male and female), sedhangkapitpancuran - 'three children and the second child is male; pancagati- 'five boys all'; and so forth. In addition, children born on the basis of time or circumstances, for example: margana - 'child born with intestine wrapped around the neck,' jempina - 'child born untimely,' including children born julungcaplok - at sunset' [2]. Krimuning is one who was born at sunset, so nicknamed as julungceplok [2].

In Javanese local wisdom, for someone who has the birth time of julungcaplok when going to the forest and meeting a tiger, it will be annexed to 'eaten'. Unlike the time of birth of the julungkembang, which is born at the time the sun will rise, even though it meets a ferocious tiger, it will not be annexed (dicaplok).Therefore, to avoid this influence, for someone born at the time of julungcaplok, it needs to be addressed (diruwat) or must be purified.

MbahJito also explained about the procedures and equipments of Ruwatan. The villagers of Alang-alang also work together in the implementation of the ruwatan ritual that Krimuning undertakes. At the time of the ritual, the name of Krimuning is purified and changed into DewiOntang-anting and furthermore known by her new name. After being purified, the villagers believe that DewiOntang-anting have a special relationship with DewiLanjar (Queen of Java's Northern Coast), so they also believed in every word of Dewi Ontanganting/Krimuning.

The event represents that the people of KarimunJawa still truly believe and do the ritual to clean themselves that affect the "cleanliness of the environment." That is in line with Ruwatan done by the people of Cetho Village. They performed ruwatan in the rituals of Mondosiyo and Dawuhan to create harmony and tranquility of the village life environment according to the philosophy of Mamayu Hayuning Bawana[4].

Similarly happened in the village of Alang-alang, Karimun Jawa. Krimuning undertakes the act of Memayu Hayuning Bawana by helping the villagers who beg him for a solution to their problems. One is the fishermen always beg Krimuning to pray for them before going to sail. Although Krimuning initially feels frustrated, because of the advice from MbahJito, she eventually always helps the people who ask her for help.

\subsection{Semedi}

Semedi is a process to the opening of the veil of the unseen nature or the enlightened process of the supernatural or God. In the process all the attention is centered to the inner realm, so that the consciousness of the outer world becomes fana - 'vanished'. The result or the accomplishment of lakusemediis to obtain illumination from the supernatural [8]. The implementation of the semedi can only be done well (perfect) when the inner self of the person is completely clean of all worldly desires. Like how it is done by Krimuning, before carrying out a semedi (tapa), she diligently prays, fasts on Monday-Thursday, and is purified.

Krimuning always practiced the semediwhile sitting cross-legged on a masked stone like a Buddha, hands arranged in such a way, facing the sea, closing her eyes, and praying. Referring to the story in the KDOA novel, Krimuning undergoes three stages until it reaches its peak of semedi, which are: 
The first semedi, Krimuning has not succeeded. Because she is stunned over the emergence of the figure of a princess and the fragrance of arum dalu flower. As Krimuning kneels to the princess and tries to communicate, she returns to worldly consciousness and falls unconscious [2]. In Javanese culture, there is pepelingajakagetanlangumunan-'do not be surprised and wonder'. Pepeling is reminding that everything in the world is God's creation. If you still have that feeling, then one forgets the existence of God, so that she or he is not strong to face it. It is symbolized by a fainted Krimuning (unconscious) encountering an extraordinary figure in front of her.

The second semedi, it is implemented after a year and a half later. Krimuning tries to perfect her semedi with guardiancy from her friends. The success of Krimuning comes from the emergence of light on her body, like an angel descending from heaven. However, Krimuning feels that her semedi is less than perfect, because it is not as expected that DewiLanjar does not show herself. Krimuning thinks that is probably because of the many people around her. At that time Krimuning returns to the worldly conscious realm [2].

In semedi experience, the power of silence can produce tremendous power, which gives automatic control of power to the human mind and heart. The uncontrolled silence will destroy everything[9]. The semedi done by Krimuning at that time was more established, the body was strong, so she did not faint again. Even the emergence of light from all over her body represents that Krimuning has attained tremendous power, so that she can obtain clues in carrying out the role of her life. Therefore, she is increasingly able to help villagers who need help, both physically and mentally ill.

The second stage of her semedi is carried out when Krimuning has not yet been purified. After being purified, Krimuning carries out the third semedi stage. This time Krimuning hopes the Northern Coast Queen descended from her wagon, according to her dream.

Then the shadow figure approaches her, Krimuning prostrates to worship the figure. She feels as expected, finally DewiLanjar, the Queen of the North Coast appeared before her. They also communicate for a moment, and Krimuning gets a message from DewiLanjar that says "segarasakisinekuwiana sing nyipta. Titah manungsa aja mung sakderma. Ngundhuh kok ora nganggo nandur? Yen wisana sing nandur, garek open-open lan njaga!"-'The sea and its content is created by someone. Humans should not just carry out obligations minimally. If you want to reap the result why do you not sow? When there is someone who sow, just keep it and preserve it!'-After the words, DewiLanjar and all the equestrian soldiers who accompanied her leaves the place. Krimuning looked down and fell silent. Finally, she looks at the last soldier swept away by the waves, but still visible, and shouts softly, "Father!" [2]

The incident indicates that Krimuning has succeeded in reaching the end of her semedi. It is symbolized by the presence of Dewi Lanjar according to her dream, even has time to communicate and gives a message to her. It represents that Krimuning has succeeded in meeting her true teacher, symbolized by the power of God that through her dream, she has known the event that will happen to herself at this time.

The achievement of semedi, as the end of the action carried out by Krimuning at the same time, represents that the people of KarimunJawa still adhere to the tradition of ancestors to overcome the problems of life. In the Javanese ancestral tradition, fasting, ruwatan, and semedi (tapa) are essential for one's spiritual elevation. One of them is the implementation of fasting which basically gives a very good and big impact to the body and mind. Fasting in a supernatural way alters the molecular system of the physical and etheric bodies and raises vibrations, so that the body becomes more sensitive to supernatural energy/power, as well as to awaken one's sixth sense ability [5]. In addition, the people of Karimun Jawa also practice 
prayers. The practice of prayers represents that they have been Muslim, but still do their ancestral tradition known as kejawen.

In the general context, kejawen is a part of the local Indonesian religion. Kejawen in public opinion includes art, culture, tradition, ritual, attitude and philosophy of Javanese people. In a special context, kejawen has the meaning of Javanese spirituality. However, it is usually not fixed on strict rules and emphasizes the concept of "equilibrium" [7]. Although they already live in modern times, the people of KarimunJawa still adhere to kejawen system, and they still blend Islamic religion with Javanese culture [10].

\section{CONCLUSION}

The mindset, attitude, and actions of harmony management for the KarimunJawa community as reflected in KDOA novel cannot be separated from the knowledge built through the empirical experience inherited from their ancestors. The background of Javanese culture in the village of Alang-alang, KarimunJawa has established a pattern lakuthat is typical of its citizens, as done by Krimuning. The laku is a local wisdom manifested in the physical level (body) and non-physical (batin) by performing the prayers, fasting, ruwatan, and semedi. It represents the characteristics of kejawen that still color the life of KarimunJawa community. MemayuHayuningBawanaphilosophy becomes a cultural space that strengthens its citizens in overcoming problems in their environment, so that wayahcandhikala can be overcome by itself and not be questioned again. The strength of cultivated laku ultimately leads to one final goal, namely the desire to maintain a harmonious life for Alang-alang villagers in KarimunJawa society. The harmony contains three meanings of life, the harmonious relationship between humans, the harmonious relationship between humans and the universe, and the harmonious relationship between humans and God.

Acknowledgement. This research is fully supported by Hibah Publikasi Internasional Terindeks untuk Tugas Akhir Mahasiswa 2018fundedby DRPM Universitas IndonesiaNo. 2012/UN2.R3.1/HKP.05.00/2018.

\section{REFERENCES}

[1] J. A. Boon and N. Mulder, "Mysticism and Everyday Life in Contemporary Java: Cultural Persistence and Change.," J. Asian Stud., 2006.

[2] W. B. Leksono, Krimuning Dewi Ontang-Anting. Semarang: Cipta Prima Nusantara, 2017.

[3] D. Afnan, "Laku Tasawuf sebagai Terapi Psikospiritual (Studi Komunikasi Transendental melalui Pendekatan Psikologi Agama pada Ajaran 'Ilmu Sejati' di Desa Karangampel Kabupaten Indramayu),” JIKE, vol. 1, no. 1, 2017.

[4] F. Ali Ikhsan, B. Setioko, and A. Suprapti, "Ecological wisdom of Hindu-Javanese community settlement in Cetho Hamlet, Lawu Mountains, Central Java, Indonesia," in IOP Conference Series: Earth and Environmental Science, 2018.

[5] S. Endraswara, Guru Sejati: Jalan untuk Menemukan Kemurnian Abadi di Antara Kekotoran Duniawi. Yogyakarta: Narasi, 2014.

[6] Mangkunagara IV, Serat Wedhatama. .

[7] M. Yana, Falsafah dan Pandangan Hidup Orang Jawa: Tata Krama, Tradisi, Pantangan, Kebiasaan dengan butir-butir Budaya Jawa, Karakter dan Ritual Masyarakat Jawa. Yogyakarta: Bintang Cemerlang, 2012.

[8] Simuh, Sufisme Jawa: Transformasi Tasawuf Islam ke Mistik Jawa. Jakarta: Uhamka Press, 2014. 
[9] A. Sarwono, The Miracle of Patient. Sabar di Masa Sulit. Jakarta: Uhamka Press, 2014.

[10] K. Saddhono, "Cultural and social change of foreign students in Indonesia: The influence of Javanese Culture in Teaching Indonesian to Speakers of Other Languages (TISOL)." IOP Conf. Ser.: Ear. and Envi. Sci.. vol. 126 no. 1 IOP Publishing, 2018. 